INSIGHTS INTO REGIONAL DEVELOPMENT

ISSN 2669-0195 (online) http://jssidoi.org/IRD/

2021 Volume 3 Number 1 (March)

http://doi.org/10.9770/IRD.2021.3.1(8)

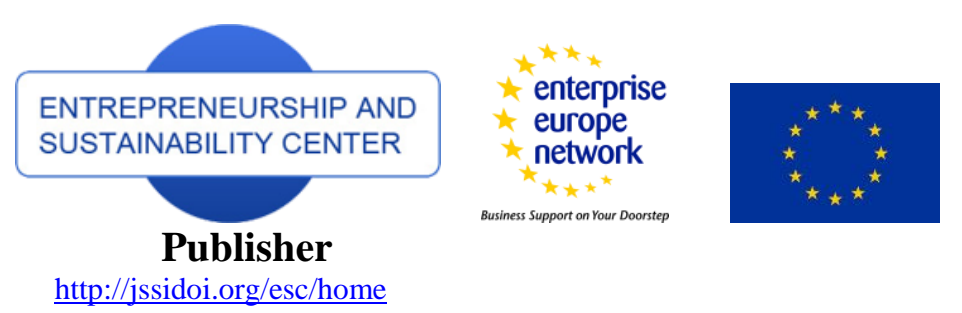

\title{
CORPORATE GOVERNANCE MECHANISMS AND FINANCIAL REPORTING QUALITY OF LISTED COMMERCIAL BANKS IN NIGERIA
}

\author{
Sunday Oseiweh Ogbeide ${ }^{1}$, Henry Usunobun Ogiugo ${ }^{2}$, Isaac Olufemi Adesuyi ${ }^{3}$ \\ 1Department of Accounting and Finance, Faculty of Humanities, Social \& Management Sciences \\ Elizade University, Ilara-Mokin, P.M.B. 002, Ondo State, Nigeria \\ ${ }^{2}$ Department of Accounting and Finance, Faculty of Management Sciences \\ AJAYI Crowther University, Ibadan, Oyo State, Nigeria \\ 3Department of Business Administration, Faculty of Humanities, Social \& Management Sciences \\ Elizade University, Ilara-Mokin, P.M.B. 002, Ondo State, Nigeria \\ E-mails: ${ }^{1}$ sunnyogbeide2017@gmail.com ${ }^{2}$ ogiugohenry@yahoo.com; Isaac.adesuyi@elizadeuniversity.edu.ng
}

Received 15 August 2020; accepted 15 December 2020; published 30 March 2021

\begin{abstract}
This study examined corporate governance mechanisms and financial reporting quality of listed commercial banks in Nigeria. The population of the study consists of all listed commercial banks on the stock exchange as at $31^{\text {st }}$ December 2018. A sample of nine (9) listed commercial banks were selected and data were collected over the period 2008 to 2018. Descriptive statistics and panel Least Square regression were used for the data analysis. The findings reveal that board size and audit committee were negative and exerted significant impact on financial reporting quality of listed commercial banks while board independence is significant and exerts a positive influence on financial reporting quality of listed commercial banks in Nigeria. Female directorship does not have a significant relationship with financial reporting quality of listed commercial banks in Nigeria. The study therefore recommends that steps should be taken by regulators to stipulate stiffer penalty on firms engaging in earnings smoothing capable of undermining corporate governance ethics and framework for banks in Nigeria as this will serve as deterrent to others and further entrench sanity.
\end{abstract}

Keywords: Board Size; Board Independence; Female Directorship; Audit Committee Size; financial Reporting Quality

Reference to this paper should be made as follows: S.O. Ogbeide., Ogiugo, H.U., \& Adesuyi, I.O. (2021). Corporate governance mechanisms and financial reporting quality of commercial banks in Nigeria. Insights into Regional Development, 3(1), 136-146. http://doi.org/10.9770/IRD.2021.3.1(8)

JEL Classifications: M41, M42

\section{Introduction}

In the competitive banking environment, effective corporate governance indicator has been identified as a potent force in the profitability of banks operating in Nigeria (James and Ibezim, 2015). The very essence of corporate governance is to monitor the ills of the directors and other management staff with a view to ensuring prudent management of scarce resources as well as financial reporting quality. Al-khonain and Al-deem (2020) opine that giant multinational firms such as Enron, WorldCom, and Tyco witnessed bankruptcies in the early 2000s due to ineffective corporate governance mechanisms and poor financial reporting. Financial reporting is a means through which an enterprise conveys information about its financial performance and condition to external users. 


\section{INSIGHTS INTO REGIONAL DEVELOPMENT}

ISSN 2669-0195 (online) http://jssidoi.org/jesi/

2021 Volume 3 Number 1 (March)

http://doi.org/10.9770/IRD.2021.3.1(8)

In Nigeria, the heightened interest in corporate governance of banks was premised on the collapse of several financial and non-financial institutions which includes the bank PHB, Spring bank Plc, Oceanic bank Plc, Intercontinental bank Plc, African petroleum Plc, Levers brother and Cadbury Plc. An investigation into the cause revealed significant, deep-rooted problems in the account preparation and also the intentional misconduct of managers which led to the concurrent sack of eight (8) bank chiefs by the governor of central bank of Nigeria and the call for an investigation of the efficacy of the monitoring and controlling of managerial and financial behavior of managers (Ndukwe \& Onwuchekwa, 2014, Paulinus, Oluchukwu \& Somtochukwu, 2018).

Shareholders are linked to the directors via the financial reporting system. The quality of financial reports relates to the extent to which relevant information about the firm's earnings is communicated to stakeholders. In order to enhance the integrity of financial reporting, companies are required to put in place, a designed structure in the form of sound corporate governance to ensure the true and fair presentation of a company's financial position. Hence, Paulinus et al. 2018 stress that financial reporting is perceived no longer as a low priority book keeping exercise, but a central function for directing a company under good corporate governance principles.

Corporate governance and financial reporting are highly interwoven. Financial reporting is considered as a crucial part of corporate governance mechanisms (Melis, 2004; Melisa and Carta, 2010; Chanatup, Aujirapongpan and Ritkaew, 2020; Tjahjadi, Harymawan, and Warsidi, 2020; Wati, Ramdany and Momon, 2020; Kulustayeva, Jondelbayeva, Nurmagambetova, Dossayeva and Bikteubayeva, 2020). Corporate governance is a major driver of quality financial reporting in firms in the light of macroeconomic challenges (Okpamen \& Ogbeide, 2020). Joseph and Ahmed (2017) emphasized that good corporate governance influences the likelihood of financial reporting in firms. Conventionally, stakeholders expect corporate transparency and quality information for decision making, which is facilitated by corporate governance practices by molding the corporate reporting process in a positive direction (Cooray, Gunarathne \& Senaratne, 2020).

Corporate governance indicators assist to ensure that financial reports are in compliance with International Financial Reporting Standards (IFRS). Board size, audit committee size, board independence and female board members are common indicators of corporate governance in the assessment of quality of reports (Zalata, Tauringana \& Tingbani, 2017). These indicators of corporate governance play a vital role in influencing the quality of financial reporting. The studies on the link between board size and financial reporting quality are mixed. For example, the researches conducted by Akshita and Sharma (2015); Christensen, Christensen, Kent and Stewart (2010) state that a small board size induces a better performance and financial reporting quality in firms. Adams and Mehran (2012) argue that some organizations need larger boards for effective monitoring. Beasley (1996) reports that a small board size has positive relationship with the likelihood of financial statement fraud while Carcello and Nagy (2004) and Farber (2005) found negative relationship between financial reporting quality and a lare board size.

Audit committees are an essential element of corporate governance (Green, 1994). The audit committee is arguably the most important of the board sub-committees (Mallin, 2007). The audit committee act independently from the executive, to ensure that the interests of shareholders are properly protected in relation to financial reporting and internal control. It is the role of the audit committee to review the scope and outcome of the audit, and to try to ensure that the objectivity of auditors is maintained. This may involve a review of the audit fee, and fees paid for any non-audit work, and the general independence of auditors. The audit committee bridges the gap between the internal and external auditors and the board, helping to ensure that the board is fully aware of all relevant issues related to the audit. The committee is to be structured to ensure reliable and high financial report as it oversees the financial reporting process (Onuorah \& Imene, 2016). In Nigeria, the audit committee was stipulated by the Companies and Allied Matters Decree 1990, now known as the Companies and Allied Matters 


\section{INSIGHTS INTO REGIONAL DEVELOPMENT}

ISSN 2669-0195 (online) http://jssidoi.org/jesi/

2021 Volume 3 Number 1 (March)

http://doi.org/10.9770/IRD.2021.3.1(8)

Act (CAMA) as amended for companies to maintain. The findings of Abbott, Parker and Peters (2004) depict that audit committee size has no considerable influence on quality of financial reporting. But, Yermack (1996) posits that a fewer audit committee improves firms' worth, agreeing with Jensen (1993) assertion that a small sized audit committee member enhances the efficiency with which the audit committee engages in oversight and control function.

Board independence means the number of independent non-executive directors on the board in relation to the total number of directors (Uwuigbe, 2011). It implies more outside directors. The assumption is that boards with a significant number of outside directors will be more independent and will make better decisions than boards dominated by insiders because of their fiduciary duty to its shareholders and their independence from management (Fama \& Jensen, 1983). An important factor that may affect the quality and accuracy of financial reports is the composition of its board members. A more independent board is likely to produce an unbiased financial statement. Peasnell, Pope \& Young (2000) and Davidson, Godwin and Kent (2005) confirmed a strong link between board independence and financial reporting. Joseph \& Ahmed (2017) also affirm that board independence has a significant positive effect on the timeliness and quality of financial reports. Other studies have however provided a contrasting opinion. According to Uwalomwa, Eluyela, Uwuigbe, Obarakpo and Falola (2018), board independence has a non-significant negative relationship with the quality of financial reports. Also, Oba (2004) earlier opined that board independence has a significantly negative effect on the quality of financial reports. The results of Ajayi and Zahiruddin (2015) who investigated the relationship between female board member and market performance showed that there is a negative significant relationship. The gender of the firms' directors has been suggested to affect corporate policies and outcomes given that women are generally more cautious.

There are growing stream of researches in the way and manner in which male and female board members bring their characteristics to reflect on their choices of leadership style and decision making process on the board (Smith, Smith \& Varner, 2006; Renee and Daniel, 2009; Duc and Thuy, 2013). Women tend to have better communal characteristics, like being kind, helpful and sensitive while men are more dominant in nature (Eagly \& Johannesen-Schmidt, 2001). The communal characteristics of women are associated with better communications among board members and also better board participation like attending board meetings (Adams \& Ferreira, 2009). A wide range of studies like Oyenike, Olayinka and Emeni (2016) affirm that female directors are riskaverse and usually support less risky policies and financial decisions compared to male directors and that female directors are stricter monitors. Adams and Ferreira (2009) opined that female board members are connected with improved profitability, stronger board monitoring and good governance credentials as a result improving the quality of financial reporting. The appointment of female directors is likely to enhance board independence and improve the shareholders' wealth (Zalata, Tauringana and Tingbani, 2017). Similarly, the appointment of female directors facilitates more informed decisions, enhances the decision-making process and improves communication among board members (Bear, Rahman \& Post, 2010). In addition, the appointment of female directors enhances the depth and breadth of discussion and deliberations, particularly those related to challenging issues. Sun, Liu and Lau (2011) documented no relationship between female board members and financial reporting quality.

\section{Literature Review}

\subsection{Empirical Review}

Adegbemi, Donald, and Ismail (2010) examined the impact of corporate governance on banks performance in Nigeria. Their research was conducted by analyzing six selected banks and using pooled data and data extracted from stock exchange fact book and CBN's annual statistical bulletins and found out that corporate governance during the period they reviewed (2005-2009) was appalling and has a negative effect on the performance of the banking sector. Bebehuk and Cohaen (2004) find out that firms that have strong corporate governance 


\section{INSIGHTS INTO REGIONAL DEVELOPMENT}

ISSN 2669-0195 (online) http://jssidoi.org/jesi/

2021 Volume 3 Number 1 (March)

http://doi.org/10.9770/IRD.2021.3.1(8)

mechanisms put in place perform better and that board size has a positive relationship with financial performance. Their studies showed that large board size enhance firm performance since there is a likelihood of more experts on the board to make better decisions.

The outcome of the study by Moses (2016) depicted that audit committee size has no significant impact on the quality of financial reporting in quoted Nigerian banks. Kantudu and Samaila (2015) used multiple regression analysis to investigate board characteristics, independent audit committee and financial reporting quality of oil marketing firms in Nigeria. The study revealed that financial reporting quality is influenced by power separation, independent directors and an independent audit committee. The finding of Anderson, Mansi and Reeb (2004) show that financial reporting is negatively related to audit committee size. Abbott, Parker and Peters (2004) found that companies with an audit committee which was independent and active, were less likely to have financial reporting misstatements. Their study investigated the relationship between audit committee effectiveness and financial reporting misstatements using the Blue Robin committee recommendations as benchmarks. Levitt (1998) pointed out that the qualified, independent and tough minded audit committees represent the most reliable guardians of the public interest. The findings of Abbot, Parker and Peters (2004) indicate that audit committee size has no considerable influence on the quality of financial reporting. The work of Lin, Li and Yang (2006) however indicated a negative association between audit committee size and financial reporting quality. Reeb (2004) posits that a larger sized audit committee spends a considerable and reasonable period to check the financial reporting process and internal control mechanism which will constitute a significant factor for the effective performance of the company. Later studies including that of Carcello and Neal (2004), Lehn, Patro, and Zhao (2009) and Netter and Yang (2008) find no association between audit committee size and financial reporting quality. Based on the inconsistencies in these results by other researchers, this study will fill the gap.

Klai and Omari (2011) examined corporate governance and financial reporting quality of Tunisian firms. Multiple regression model was used and the results revealed that lack of board independence and a high level of ownership affects Tunisian firms. Kyereboad-coleman (2007) examined board independence and the size of audit committee. The findings from the study showed that larger audit committee and independent board improves firm value. The study of Cornett, Mc Nutt and Tehranian (2009) revealed that board independence is negatively related to financial reporting quality. Khan and Kotishwar (2011) found that independent non-executive directors are able to monitor and control the chairman/ chief executive. They serve as a link to the external environment and help to maintain an ethical climate. The findings of Bushman and Vafeas (2005) concluded that the quality of information contained in the financial reports increases when there is an increase in the percentage of outside independent directors. Davidson et al (2005), Klien (2002) recorded positive relationship between board independence and financial reporting quality while Kao and Chen (2004) documented a negative relationship between board independence and financial reporting quality when they examined firms in Taiwan and Hong Kong. No significant relationship was found by Shin (2004) between the quality of financial reporting and board independence in Canadian firms which is similar to the findings of Abdullah and Mohammed (2004) for Malaysian firms. Petra (2007) opined that managers cannot be controlled by independent directors because these directors are not competent enough and do not have any effect in ensuring the quality of financial reporting. In addition, Ho and Wong (2001) found no relationship between the proportion of non-executive directors and information disclosure.

Carter, Simkins and Simpson (2003) study shows that female directors are likely to display more independent thinking than male directors which is crucial for effective board oversight. Daily, Certo and Dalton, (2000) observe that compared to all-male boards, women bring different viewpoints to the boardroom and facilitate more informed decisions that increase the level of transparency at the board level. The results of Mario and Garofalo (2016) suggest that while banks with female executive's experience significantly higher financial performance under low competition, they tend to underperform when there is increased competition. Their findings also show that the presence of female leaders improves the capital stability of banks subject to greater competition. Other 


\section{INSIGHTS INTO REGIONAL DEVELOPMENT}

ISSN 2669-0195 (online) http://jssidoi.org/jesi/

2021 Volume 3 Number 1 (March)

http://doi.org/10.9770/IRD.2021.3.1(8)

studies, like Adams \& Ferreira (2007), show a negative association between the ratio of female directors on the board and operational firm performance. Adegbie, Folajimi and Fofah (2015) adopted survey research design with the use of structured questionnaire to obtain the opinion of regulators and operators regarding ethics, corporate governance and financial reporting in the Nigerian banking industry (global role of international financial reporting). It was discovered that non-compliance with relevant ethical codes and poor corporate governance affected the preparation of quality and faithful financial reports. The study stated that poor ethical and corporate governance are still some of the major challenges Nigerian banks are facing. The study of Onuorah and Imene (2016) evaluated corporate governance measure indicators on the firm quality of financial reporting in Nigeria on some selected companies including brewery, banking, oil and gas, and beverage companies. The results from the economic analysis conducted revealed that the correlation among corporate governance indicators of board size, board independence, audit committee size, quality of external audit and board experience on the financial reporting quality was $93.47 \%$. It further showed that quality of external audit, board experience and board size had a positive impact on the financial reporting quality whilst board independence and audit committee size negatively affect financial reporting quality. Tanko and Kolawole (2008), Jackling and Johl (2009) and Francis, Hasan and $\mathrm{Wu}$ (2012) found positive and significant association between board independence and financial reporting quality in conformity with the agency and resource dependency theories.

\section{Methodology}

The study uses descriptive and ex post facto research designs. The population of the study consists of the ten (10) commercial banks listed on the Nigeria Stick exchange as at $31^{\text {st }}$ December 2018 (The Nigerian Stock Exchange website and Fact Book, 2018). This study employs the judgmental sampling technique to select a sample size of nine (9) listed commercial banks in the period under reference. The justification for the use of this technique is premised on the fact that the selected banks are in the best position to provide information required. The data used for this study were secondary data derived from the annual reports of nine (9) individual commercial banks which was obtained from the Nigerian Stock Exchange (NSE), making up the sample size for the period 11 years from 2008-2018. The annual report from which the data will be extracted is possibly the most important document of a firm, especially as regards its financial status.

\subsection{Method of Data Analysis}

To analyze the data on corporate governance variables such as board size, audit committee size, board independence and female board member. Panel unit root test using the ADF - Fisher Chi-square method was used to determine the stationarity of the variables. If p-value >ADF - Fisher critical value of 0.05, accept null hypothesis, i.e. unit root exists, mean data is non stationary (Joseph \& Ahmed, 2017). Also, if p-value<ADF Fisher Chi-square critical value 0.05 , reject null hypothesis, i.e. unit root does not exist. That is, the mean data is stationary. The correlation matrix shows the association between the variables. The correlation analysis shows only the degree of association between variables and does not permit the researcher to make causal inferences regarding the relationship between variables (Marczyk et al., 2005). Panel least square was used to ascertain the impact of the independent variables on financial reporting quality of the sampled commercial banks.

\subsection{Model Specification}

The model used by Adebiyi (2017) was modified and adapted. The following general empirical research model was developed in the form of multiple regression equation:

$\mathrm{FRQ}=\boldsymbol{f}(\mathrm{BDSZ}, \mathrm{ADCSZ}, \mathrm{BDIND}, \mathrm{FBDM})$ it-

Yit $=\beta 0+\Sigma \beta$ KXit + Eit-

Where: Yit $=$ the dependent variables for time period t. $\beta 0=$ is the intercept. $\beta \mathrm{K}=$ represents the coefficients of the Xit variables. Xit =represents the explanatory variables. Eit= is the error term. As relating to corporate governance mechanisms and financial reporting quality, the model data is therefore stated as follows: 
$\mathrm{FRQit}=\beta 0+\beta 1($ BDSZit $)+\beta 2($ ADCSZit $)+\beta 3($ BDINDit $)+\beta 4($ FBDMit $)+\varepsilon i t-$

\subsection{Variable Description}

$\mathrm{FRQ}=$ Financial Reporting Quality; BDSZ = Board Size, ADCSZ= Audit Committee Size ; BDIND = Board Independence; FBDM = Female Board Member (see Table 1)

Table 1: Measurement of Variables

\begin{tabular}{|c|c|c|c|c|}
\hline $\mathbf{S} / \mathbf{N}$ & Variables & Types of Variables & Measurement of Variables & Source \\
\hline 1. & $\begin{array}{c}\text { Financial Reporting } \\
\text { Quality }\end{array}$ & Dependent & $\begin{array}{c}\text { Accrual method } \\
\text { Total accrual = net income }- \text { cash flow from } \\
\text { operating activities }\end{array}$ & Bako (2013) \\
\hline 2. & Board Size & Independent & Total number of members on the board & Chen (2014) \\
\hline 3. & $\begin{array}{l}\text { Audit Committee } \\
\text { Size }\end{array}$ & Independent & $\begin{array}{l}\text { The proportion of members serving on the audit } \\
\text { committee }\end{array}$ & $\begin{array}{l}\text { Ming and Lee } \\
\text { (2014) }\end{array}$ \\
\hline \multirow[t]{2}{*}{4.} & \multirow[t]{2}{*}{ Board Independence } & \multirow[t]{2}{*}{ Independent } & Number of non - executive directors & \multirow{2}{*}{$\begin{array}{c}\text { Fama and } \\
\text { Jensen (1983) }\end{array}$} \\
\hline & & & Total board size & \\
\hline 5. & $\begin{array}{l}\text { Female Board } \\
\text { Member }\end{array}$ & Independent & Blau (1977) index method & $\begin{array}{l}\text { Bear, Rahman } \\
\text { and Post (2010) }\end{array}$ \\
\hline
\end{tabular}

Source: Researcher's Compilation, 2020

\subsection{Empirical Analysis}

Table 2: Correlation Matrix

\begin{tabular}{c|ccccc} 
& FRQ & BDSZ & ADCSZ & BDIND & FBDM \\
\hline FRQ & 1.00 & & & & \\
BDSZ & -0.06 & 1.00 & & & \\
ADCSZ & -0.02 & 0.03 & 1.00 & 1.00 & \\
BDIND & -0.16 & -0.16 & -0.12 & -0.08 & 1.00 \\
FBDM & -0.06 & -0.10 & -0.23 & \\
\hline \hline
\end{tabular}

Source: Eview 8.0 Output, 2020

Table 2 shows the correlations coefficient between the dependent variable financial reporting quality (FRQ) and the independent variables. As seen above, it is noted that the financial reporting quality has a weak and negative relationship with board size (BDSZ) $(r=-0.06)$, audit committee size (ADCSZ) $(r=-0.02)$, board independence (BDIND) $(\mathrm{r}=-0.16)$, and female board member $(\mathrm{FBDM})(\mathrm{r}=-0.06)$. The correlations imply that the independent variables are not strong enough to positively influence financial reporting quality. Board size (BDSZ) is negatively correlated with board independence (BDIND) $(\mathrm{r}=-0.16)$, and female board member (FBDM) $(\mathrm{r}=-$ 0.01 ). While board size is positive with audit committee size (ADCSZ) $(r=0.03)$. Audit committee size (ADCSZ) is negatively associated with board independence and female board member $(r=-0.12, r=-0.23)$. Board independence (BDIND) and female board member $(\mathrm{FBDM})$ are negatively correlated $(\mathrm{r}=-0.08)$. The results suggest the absence of multicollinearity among the variables in the model. Since correlation does not necessarily mean that there is a causal relationship (Woolridge, 2000), there is need to conduct regression analysis in order to estimate causal relationship. Therefore, Panel least square regression is conducted (Table 3 ). 
INSIGHTS INTO REGIONAL DEVELOPMENT

ISSN 2669-0195 (online) http://jssidoi.org/jesi/

2021 Volume 3 Number 1 (March)

http://doi.org/10.9770/IRD.2021.3.1(8)

Table 3. Panel Least Square Regression

Dependent Variable: FRQ

Method: Panel Least Squares

Date: 08/15/19 Time: 19:43

Sample (adjusted): 20112018

Periods included: 8

Cross-sections included: 9

Total panel (balanced) observations: 72

White cross-section standard errors \& covariance (d.f. corrected)

\begin{tabular}{|c|c|c|c|c|}
\hline Variable & Coefficient & Std. Error & t-Statistic & Prob. \\
\hline $\mathrm{C}$ & 16275130 & 35611106 & 0.457024 & 0.6491 \\
\hline $\mathrm{D}(\mathrm{BDSZ})$ & -4358363 & 3137089. & -1.389017 & 0.0440 \\
\hline $\mathrm{D}(\mathrm{ADCSZ})$ & -48736561 & 24457841 & -1.992676 & 0.0304 \\
\hline $\mathrm{D}(\mathrm{BDIND})$ & $-2.45 \mathrm{E}+08$ & $1.26 \mathrm{E}+08$ & -1.946497 & 0.0318 \\
\hline FBDM & -41254931 & $1.03 \mathrm{E}+08$ & -0.398976 & 0.6912 \\
\hline R-squared & 0.685446 & \multicolumn{2}{|c|}{ Mean dependent var } & 4648358. \\
\hline Adjusted R-squared & 0.630846 & \multicolumn{2}{|c|}{ S.D. dependent var } & $1.32 \mathrm{E}+08$ \\
\hline S.E. of regression & $1.30 \mathrm{E}+08$ & \multicolumn{2}{|c|}{ Akaike info criterion } & 40.27706 \\
\hline Sum squared resid & $1.14 \mathrm{E}+18$ & \multicolumn{2}{|c|}{ Schwarz criterion } & 40.43516 \\
\hline Log likelihood & -1444.974 & \multicolumn{2}{|c|}{ Hannan-Quinn criter. } & 40.34000 \\
\hline F-statistic & 11.564940 & \multicolumn{2}{|c|}{ Durbin-Watson stat } & 2.000399 \\
\hline Prob(F-statistic) & 0.000809 & & & \\
\hline
\end{tabular}

Source: Eview 8.0 Output, 2020

R-Square is the ratio of changes in the dependent variable i.e. financial reporting quality (FRQ) which can be predicted from the independent variables, board size (BDSZ), audit committee size (ADCSZ), board independence (BDIND), and female board member (FBDM) of the nine selected banks. This value indicates that 0.6854 i.e. $68.54 \%$ of the changes in financial reporting quality (FRQ) scores can be predicted from board size (BDSZ), audit committee size (ADCSZ), board independence (BDIND), and female board member (FBDM). Also the adjusted R-square endeavours to give a more reliable value to estimate, hence the adjusted $\mathrm{R}^{2}$ value of 0.630846 i.e. $63.08 \%$ shows the actual changes in the financial reporting quality (FRQ), which is due to the change in independent variables; board size (BDSZ), audit committee size (ADCSZ), board independence (BDIND), and female board member (FBDM). Also the F-statistic (11.564940) is significant at 5\% level since the probability of its value (0.000809) is lesser than the 0.05 level of significance. This simply implies that the test is statistically significant and the model can be used for further speculation. Furthermore, the Durbin-Watson statistics of 2.000399 shows there is an absence of serial correlation or autocorrelation problem of regression in the model. These approximately conform to the benchmark of 2.0 for the absence of autocorrelation problem of regression. It suggests that the result is good for policy prescription. 
INSIGHTS INTO REGIONAL DEVELOPMENT

ISSN 2669-0195 (online) http://jssidoi.org/jesi/

2021 Volume 3 Number 1 (March)

http://doi.org/10.9770/IRD.2021.3.1(8)

\subsection{Discussion of Findings}

The study assessed corporate governance mechanisms and financial reporting quality of listed commercial banks in Nigeria. Based on the first hypotheses, it is seen that board size does have a significant relationship with the financial reporting quality of listed commercial banks in Nigeria. This finding is consistent with the view of Ajayi and Zahiruddin (2016) where they investigated the relationship between corporate governance mechanisms and listed firm performance using dynamic panel data through a period 2005 to 2015. Their findings showed that board size have a negative and is significant on the accounting performance of firms. Similarly, the results corroborate the view of Uwuigbe (2011) on corporate governance and financial performance of banks in Nigeria using panel data regression analysis to analyze the relationship that exists between corporate governance and the financial performance of banks. The finding shows board size had significant negative effect on the financial performance of listed banks. However, the results of the first does not support the view of findings of Bebehuk and Cohaen (2004) where they showed that large board size enhance firm performance since there is a likelihood of more experts on the board to make better decisions.

It was observed that audit committee size does have a significant relationship with financial reporting quality of listed commercial banks in Nigeria. This finding is in line with the view of Onuorah and Imene (2016) where they evaluated corporate governance measure indicators on the firm quality of financial reporting in Nigeria on some selected companies including brewery, banking, oil and gas, and beverage companies. Their results revealed that board independence and audit committee size negatively affect financial reporting quality. However, the results disagreed with the view of Kyereboad-coleman (2007) who examined board independence and the size of audit committee. The findings from the study showed that larger audit committee and independent board improves firm value. Board independence does have a significant relationship with financial reporting quality of listed commercial banks in Nigeria. This result is in tandem with the view of Kantudu and Samaila (2015) who used multiple regression analysis to investigate board characteristics, independent audit committee and financial reporting quality of oil marketing firms in Nigeria. The study revealed that financial reporting quality is influenced by power separation, independent directors and an independent audit committee. Also the results support the findings of Klai and Omari (2011) they examined corporate governance and financial reporting quality of Tunisian firms. Their results revealed that lack of board independence and a high level of ownership affects Tunisian firms. Female directorship does not have a significant relationship with financial reporting quality of listed commercial banks in Nigeria. This result does not support the view of Carter, Simkins and Simpson (2003). They showed in their findings that female directors are likely to display more independent thinking than male directors which is crucial for effective board oversight. The results also disagreed with the view of Adams and Ferreira (2009) which they opined that female board members are connected with improved profitability, stronger board monitoring and good governance credentials as a result improving the quality of financial reporting. Furthermore, the result is in contrast with the view that the appointment of female director is likely to enhance board independence and improve the shareholders' wealth (Zalata, Tauringana \& Tingbani, 2017).

\section{Conclusion and Recommendations}

The survival and stability of any financial sector depends on the quality of its governance. In spite several reforms put to strengthen this sector, banks were still prone to failure. The loss associated with this failure is enormous on their reputation and industrial growth. Strong governance framework that enhances compliance and sanction non- 


\section{INSIGHTS INTO REGIONAL DEVELOPMENT}

ISSN 2669-0195 (online) http://jssidoi.org/jesi/

2021 Volume 3 Number 1 (March)

http://doi.org/10.9770/IRD.2021.3.1(8)

compliance to corporate governance codes becomes imperative. Hence, the rationale of the study was to examine the impact of corporate governance mechanisms and financial reporting quality of listed banks in Nigeria, with particular reference to nine (9) selected banks quoted in Nigeria Stock exchange, which are Access bank, Fidelity bank, GT bank, sterling bank, Union bank, UBA, Unity bank, WEMA bank, and Zenith bank. Based on the Panel regression results the study, the study showed that board size does have a significant but negative relationship with the financial reporting quality of listed commercial banks in Nigeria., also that audit committee size does have a significant but negative relationship with financial reporting quality of listed commercial banks in Nigeria. On the other hand, board independence does have a significant and positive relationship with financial reporting quality of listed commercial banks in Nigeria. However, that female directorship failed to have a significant relationship with financial reporting quality of listed commercial banks in Nigeria. This study concludes that corporate governance mechanisms have an impact on financial reporting quality of listed commercial banks in Nigeria. Conclusively, corporate governance has significant effect on the quality of financial reporting in the listed commercial banks in Nigeria.

Based on the findings of this research, we therefore present the following recommendations which will be useful, especially to stakeholders. Efforts to improve corporate governance should focus on the size of boards, by maintaining an optimum size, since it has a negative relationship with the quality of financial reporting. The number of members in the audit committee should also be kept at an optimum. This is because a committee with too many members will lead to a decrease in the quality of financial reporting in listed commercial banks in Nigeria. Since the relationship between board independence and quality of financial reporting is positive, in order to have proper monitoring by independent directors, bank regulatory bodies should require additional disclosure of financial or personal ties between directors (or the organizations they work for) and the company or its CEO. By so doing, they will be more completely independent. Although female directorship was found not to have a significant effect with financial reporting quality of listed banks in Nigeria, it is recommended that banks stick to disclosing the number of females on the board, and try to have more female directors for the purpose of inclusivity.

\section{References:}

Abbott, I., Parker, S. \& Peters, G. F. (2004). Audit committee characteristics and restatements. Journal of Practice and Theory, 23(1), 6987.

Adams, R. B., \& Ferreira, F. (2009). Women in the boardroom and their impact on governance and performance. Journal of Financial Economics, 94, 291-309.

Adegbemi, B. O., Donald, I. O., \& Ismail, O. F. (2010). Corporate Governance and Bank Performance: A Pooled Study of Selected Banks in Nigeria. European Scientific Journal, 8(28).

Adegbie, F., \& Fofah, E., T. (2015). Ethics, corporate governance and financial reporting in the Nigerian banking industry: global role of international financial reporting standards. Accounting and Finance Research 5(1), 50-65. http://doi.org/10.5430/afr.v5n1p50

Ajayi, O. D., \& Zahiruddin, B. G. (2016). Corporate governance mechanisms: the determinants of listed firm performance in Nigeria. Research Journal of Finance and Accounting 7(8), 68-85.

Akshita, A., \& Sharma, C. (2015). Impact of firm performance on board characteristics: Empirical evidence from India. IIM Kozhikode Society \& Management Review, 4(1), 53- 70.

AL-khoain, S., \& AL-deem, K. (2020). Corporate governance and financial reporting quality: preliminary evidence from Saudi Arabia. Finamcial Markets, Institutions and Risks, 4(1), 109-116.

Beasley, M. S. (1996). An Empirical analysis of the relation between the board of director composition and financial statement fraud. The Accounting Review, 71(4), 443-465.

Carcello, J. V., \& Nagy, A. L. (2004). Client Size, auditor specialization and fraudulent financial reporting. Managerial Auditing Journal, 19(5), 651-668.

Carter, D.A., Simkins, B.J. \& Simpson, W.G. (2003). Corporate governance, board diversity and firm value. Financial Review, 38 , $33-53$.

Chanatup, S., Aujirapongpan, S., \& Ritkaew, S. (2020). The influence of corporate governance mechanism on the integrated financial reporting and investment risk of Thai listed companies. Entrepreneurship and Sustainability Issues, 7(4), $2818-2831$. http://doi.org/10.9770/jesi.2020.7.4(16) 


\section{INSIGHTS INTO REGIONAL DEVELOPMENT}

ISSN 2669-0195 (online) http://jssidoi.org/jesi/

2021 Volume 3 Number 1 (March)

http://doi.org/10.9770/IRD.2021.3.1(8)

Christensen, J., Kent, P., \& Stewart, J. (2010). Corporate governance and company performance in Australia. Australian Accounting Review, 20(4), 372- 386

Cooray, T., Gunarathne, N., \& Senaratne, S. (2020). Does corporate governance affect the quality of integrated reporting? Sustainability Accounting Journal, 12, 1-30.

Daily, C.M., Certo, S.T. \& Dalton, D.R. (2000). The future of corporate women: progress toward the executive suite and the boardroom? Burke, R.J. and Mattis M.C. (Ed.), Women on corporate boards of directors: international challenges and opportunities. The Netherlands: Kluwer Academic Publishers, $11-23$.

Davidson, R., Godwin, S. J., \& Kent, P. (2005). Internal governance structures and earnings management. Journal of Accounting and Finance, 45, 241-467.

Duc, V., \& Thuy, P. (2013). Corporate governance and firm performance: Empirical evidence from Vietnam. Working Paper, Open University, Ho Chi Minh City, Vietnam.

Eagly, A. H., \& Johannesen-Schmidt, M. C., (2001). The Leadership Styles of Women and Men. Journal of Social Issues, 57(4), 781 -797.

Fama, F., \& Jensen, M. C., (1983). Separation of ownership and control. Journal of Law and Economics, $26(2), 301$ - 325.

Farber, D. (2005). Restoring trust after fraud: does corporate governance matter? The Accounting Review, 80, $539-561$.

Green, D. (1994). Canadian audit committees and their contribution to corporate governance. Journal of International Accounting, Auditing and Taxation, 3(2), 135-151.

James, N. O., \& Ibezim, A. U. (20 15). The effect of poor corporate governance on the performance of Nigerian banks. Journal of Innovative Research and Advanced Studies, 3(1), 3-25.

Jensen, M. (1993). The Modern Industrial Revolution: Exit and Failure of Internal Control Systems. Journal of Finance, 48(3), 831-880

Joseph, B. A., \& Ahmed, A. B., (2017). Corporate governance and financial reporting quality in Nigeria. International journal of information research and review, 4(2), 3749-3753.

Kantudu, A. L., \& Samaila, I. A. (2015). Board characteristics, independent audit committee and financial reporting quality of oil marketing firms: Evidence from Nigeria. Journal of Finance Accounting and Management, 6(12), 15-23.

Khan, M. A., \& Kotishwar, A. (2011), the role of independent directors in corporate governance: A critical evaluation. International Journal of Research in Computer Application and Mnagament, 1(5), 30-45.

Klai, N., \& Omri, A. (2011). Corporate governance and financial reporting quality: the case of Tunisian firms. Internantional Business Research, 4(1), 56-65.

Klein, A. (2002). Economic determinants of audit committee effectiveness. The Accounting Review, 3(1), 435-454.

Kulustayeva, A., Jondelbayeva, A., Nurmagambetova, A., Dossayeva, A., \& Bikteubayeva, A. (2020). Financial data reporting analysis of the factors influencing on profitability for insurance companies. Entrepreneurship and Sustainability Issues, 7(3), $2394-2406$. https://doi.org/10.9770/jesi.2020.7.3(62)

Lehn, K. M., Patro, S., \& Zhao, M. (2009). Determinants of the size and composition of US corporate boards. Financial Management, 38(4), 747-780.

Lin, J. W., Li, J. F., \& Yang, J. S. (2006). The Effect of Audit Committee Performance on Earnings Quality. Managerial Auditing Journal, $21(9), 921-933$.

Mallin, C. A. (2007). Corporate governance, second edition, oxford university press: Oxford.

Marshall, J. B. (2015). Corporate governance practices: An overview of the evolution of corporate governance codes in Nigeria. International Journal of Business \& Law Research, 3(3), 49-65.

Melis, A. (2004). Financial Reporting, Corporate Communication and Governance: Corporate Ownership and Control. Journal of Management and Governance 1(2), 31-37.

Melis. A., \& Carta, S. (2010). Does accounting regulation enhance corporate governance? Evidence from the disclosure of share-based remuneration. Journal of Management and Governance, 14(4), 435-446.

Moses, T. (2016). The impact of audit committee size on the quality of financial reporting in quoted Nigerian banks. International Journal of Advanced Academic Research, 2(5), 62-75.

Ndukwe, G., \& Onwuchekwa, T. (2014). Corporate governance and banks' financial reporting quality in Nigeria. Research Journal of Business and Social Sciences, 2(8), 68-85.

Oba, V. C. (2004). Board of dynamics and financial reporting quality in Nigeria. Review of International Corporative Management, 15(2), 226-236.

Okpamen, P., \& Ogbeide, S.O. (2020). Board reputation capital and financial performance of listed firms in Nigeria. Insights into Regional Development, 2(4), 750-758

Onuorah, A., \& Imene, O. F. (2016). Corporate governance and financial reporting quality in selected Nigerian company. International Journal of Management Science and Business Administration, 2(3), 7-16. http://doi.org/10.18775/ijmsba

Oyenike, O., Olayinka, E., \& Emeni, F. (2016). Female directors and tax aggressiveness of listed banks in Nigeria. Third international conference on African development issues, 293-299.

Paulinus, E.C., Oluchukwu, N., \& Somtochukwu, O. (2018). Empirical investigation of corporate governance and financial reporting quality of quoted companies in Nigeria. International Journal of Economics, Business and Management Research, 1(5), $117-137$.

Peasnell, K. V., Pope, P. F., \& Young, S. (2000). Accrual management to meet earnings targets: UK evidence pre and post Cadbury. British Accounting Review, 32(4), 415-445.

Rene, B. A., \& Daniel, F. (2009). Women in the boardroom and their impact on governance and performance. Journal of Financial Economics, 94, 291-309. 
INSIGHTS INTO REGIONAL DEVELOPMENT

ISSN 2669-0195 (online) http://jssidoi.org/jesi/

2021 Volume 3 Number 1 (March)

http://doi.org/10.9770/IRD.2021.3.1(8)

Smith, N., Smith V., \& Verner, M. (2006). Do women in top management affect firm Performance? International Journal of Productivity and Performance Management, 55 (7), 569-593.

Sun, J., Liu, G., \& Lan, G. (2011). Does female directorship on independent audit committee constrain earnings management? Journal of Business Ethics, 99(3), 369-382.

Tanko, M., \& Kolawole, O. O. (2010). Corporate governance and firm's performance in Nigeria. Accounting Research, 5(1), $23-40$.

Tjahjadi, B., Harymawan, I., \& Warsidi, N.S. (2020). Implementation of integrated reporting: a cross-countries' study. Entrepreneurship and Sustainability Issues, 7(4), 2832-2850. http://doi.org/10.9770/jesi.2020.7.4(17)

Uwalomwa, U., Eluyela, D., Uwuigbe, O., Obarakpo, T., \& Falola, I. (2018). Corporate governance and quality of financial statements: a study of listed Nigerian banks. Banks and Banks Systems 13(3), 12-23.

Wati, L. N., Ramdany, \& Momon. 2020. Does corporate governance affect financial reporting quality of politically connected firms? Entrepreneurship and Sustainability Issues, 7(3), 2126-2143. https://doi.org/10.9770/jesi.2020.7.3(45)

Yermack, D. (1996). Higher market valuation of companies with small board of directors. Journal of Financial Economies 9(3), 295-316.

Zalata, W., Tauringana, K., \& Tingbani, Q. (2017). Board composition and financial reporting quality of deposit money banks in Nigeria. International Journal of Innovative Finance and Economics Research 5(4), 97-104.

Sunday Oseiweh OGBEIDE is a Senior Active Researcher in, and Lecturer of Finance in the Department of Accunting and Finance, Faculty of Humanities, Social \& Management Sciences, Elizade University, P.M. B. 002, Ilara-mokin, Ondo State, Nigeria. He holds the Bachelor of Science (B.Sc) degree in Accounting, Master of Science (M.Sc. Finance) degree and Doctor of Philosophy (Ph.D. Finance) degree from the prestigious University of Benin, Edo State, Nigeria. There are over 12000 reads of his articles by researchers all over the world. His area of specliazation include Standard Finance and Behaviuoral Finance.

ORCID ID: https://orcid.org/0000-0002-2818-7757

Henry Usunobun OGIUGO is a Senior Lecturer of Finance in the Department of Accunting and Finance, Faculty of Management Sciences, AJAYI Crowther University, Oyo State, Nigeria. He holds the Bachelor of Science (B.Sc) degree in Banking and Finance, Master of Science (M.Sc. Finance) degree and Doctor of Philosophy (Ph.D. Finance) degree from the University of Benin, Edo State, Nigeria. His area of specliazation include Capital Market and Portfoilio Optimization.

ORCID ID: https://orcid.org/0000-0001-5395-9897

Isaac Olufemi ADESUYI is a Lecturer in the Department of Business Administatrion, Faculty of Humanities, Social \& Management Sciences, Elizade University, Ilara-mokin; Ondo State, Nigeria. He holds the National Diploma in Mechabical Engineering, and Higher National Diploma (HND) in Mechanical Engineering from Yaba College of Technology (YCT), Lagos State; Post graduate Diploma (PGD) in Business Administration, Executive Master in Business Administration (MBA) from the University of Calabar; Master of Science (M.Sc) in Business Management from University of Calabar, Nigeria and Doctor of Philosophy (Ph.D. Business Management) from Ebonyi State University, Nigeria. His area of specliazation include Business Management and Operation Research. ORCID ID: https://orcid.org/0000-0003-3166-6385

Make your research more visible, join the Twitter account of INSIGHTS INTO REGIONAL DEVELOPMENT: @ IntoInsights

Register for an ORCID ID: https://orcid.org/register

Copyright (C) 2021 by author(s) and VsI Entrepreneurship and Sustainability Center

This work is licensed under the Creative Commons Attribution International License (CC BY).

http://creativecommons.org/licenses/by/4.0/

cC) (i) Open Access 